\title{
OBLICZA ORMIAŃSKO-AZERBEJDŻAŃSKIEGO KONFLIKTU O GÓRSKI KARABACH
}

\author{
GENEZA ANTAGONIZMÓW
}

erytorium Górskiego Karabachu stało się przed-
miotem ormiańsko-azerbejdżańskich sporów na
długo przed ustanowieniem władzy radzieckiej na Kaukazie. Na początku XIX w. ludność muzułmańska pokojowo koegzystowała z ludnością ormiańską, której część była zormianizowanymi Albanami'. Jak podaje historyk George Bournoutian, do czasu podboju przez Rosję Ormianie stanowili zaledwie 20\% ludności Armenii Wschodniej, natomiast muzułmanie $80 \%{ }^{2}$. Władze carskie prowadzity jednak systematyczną akcję osied-

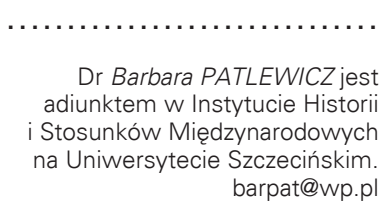

\section{-....}

1 Albania Kaukaska to historyczne królestwo powstałe w II w. p.n.e., na terenie obecnego Azerbejdżanu i południowej części Dagestanu. W 65 n.e. próbowali je opanować Rzymianie. Albania była sojuszniczką Rzymu w jego starciach m.in. z Partami. W latach 252-253 kraj został podbity przez Sasanidów, stając się jedną z satrapii (satrapia Albanii). W 387 r. dokonano podziału Albanii między Persję a Bizancjum. W połowie VII w. Albania przeszła pod panowanie arabskie i od tej pory zaprzestano używania jej nazwy w kontekście regionu czy jednostki politycznej, a nowi władcy zjednoczyli kraj z Armenią. Por.: 3. И. Ямпольский, Древняя Албания в III-I вв. до н. Э., Баку 1962; Т. Мамедов, Албания и Атропатена по древнеармянским источникам (IV-VII вв.), Баку 1977; Ф. Мамедова, История албан. Моисея Каланкатуйского как источник по общественному строю раннесредневековой Албании, Баку 1977; R. H. Hewsen, Ethno-History and the Armenian Influence upon the Caucasian Albanians, [w:] T.J. Samuelian, Classical Armenian Culture. Influences and Creativity, Chicago 1982, s. 27-40; А.А. Акопян, Албания-Алуанк в греко-латинских и дпевнеармянских источниках, Ереван 1987; Т. Мамедов, Кавказская Албания, Баку 1993; А. Алекперов, Кавказская Албания - тюркский народ, тюркская история, „Зеркало”, 7-21 kwietnia 2007, s. 4-5.

2 W 1805 r. populacja chanatu karabachskiego osiągnęła 10000 rodzin, ale w 1808 r. zmniejszyła się do 7474 rodzin. Populacja ponownie wzrosła po 1808 r. i według oficjalnych danych w 1810 r. w Karabachu zamieszkiwało 12000 rodzin, z których 2500 było ormiańskimi. Istotnym dokumentem potwierdzającym zaludnienie i narodowości populacji zamieszkującej Karabach był rejestr podatkowy sporządzony dla prowincji przez carskich urzędników Aleksandra Jermołowa i Pawła Mogilewskiego. Rejestr opracowany został w 1823 r. i odnosił się do przynależności etnicznej rodzin zamieszkujących Szuszę i wsie karabachskie. Ówcześnie chanat zamieszkiwało 90000 ludzi. W prowincji było jedno miasto i około 600 wsi, z których 150 było ormiańskich. Według rejestru w Karabachu żyło 15729 azerbejdżańskich rodzin, z tego w Szuszy było 1111, a we wsiach 14 618. Ogółem rodzin ormiańskich było 4366, z czego w mieście 421, a na wsiach 3945. G. Bournoutian, The Ethnic Composition and the Socio-Economic Condition of Eastern Armenia in the First Half of the Nineteenth Century, [w:] Transcaucasia. Nationalism and Social Change, red. R.G. Suny, Michigan 1996, s. 211-233; И. Алиев, Нагорный Карабах, Баку 1989, s. 75 zа: Присоединение Восточной Армении к России, t. 1, Еереван 1972, s. 562-563; Х.Д. Халилов, Из истории Карабаха, [w:] История Азербайджана по документам и публикациям, pod red. 3.М. Буниятова, Баку 1990, s. 39. Por.: Описание Карабахской провиннции, составленное на 1823 году, по распоряжению лавноуправляющего в Грузии Ермолова действительным статским советником Могилевским и полковником Ермоловым 2-м., Тбилиси 1866. 
lania Ormian na terytorium dzisiejszej Armenii, Karabachu i Nachiczewanu, co w konsekwencji doprowadziło do zmian demograficznych na niekorzyść ludności muzułmańskiej3. Co prawda, społeczność ormiańska liczebnie ustępowała muzułmanom, ale była bardziej operatywna i lepiej wykształcona. Z czasem Ormianie zaczęli być postrzegani jako grupa uprzywilejowana. Wynikało to ze specjalnego traktowania ich przez władze carskie, które w chrześcijańskiej ludności upatrywały wsparcia dla swej ekspansywnej polityki w regionie i zwolenników w wojnach z Imperium Osmańskim. W latach 20. XIX w. Rosja nasiliła procesy unifikacyjne na Zakaukaziu. Dla Azerbejdżanu oznaczało to utrwalenie podziału terytorium i gorsze traktowanie ludności muzułmańskiej. Utworzono 7 rosyjskich jednostek administracyjnych: Baku, Derbent, Szeki, Karabach, Szyrwan, Tałysz i Kubę pod zwierzchnictwem wojskowych komendantów-naczalników, którzy przejęli władzę od lokalnych chanów.

Kolonizacja Ormian na terenach muzułmańskich wzrastała po każdym konflikcie z udziatem Imperium Rosyjskiego. Zwłaszcza po wojnie krymskiej i wojnie rosyjsko-tureckiej z lat 1876-1878. Przyczyniła się do tego także masakra Ormian w Anatolii Wschodniej, dokonana przez Kurdów za czasów panowania suttana Abdulhamida II w połowie lat 80. XIX w. Spotęgowało to kolejny napływ Ormian, a ich liczba na Zakaukaziu osiągnęła blisko $1250000^{4}$. Mocarstwa europejskie wprawdzie podejmowały interwencje w obronie praw mniejszości chrześcijańskich, lecz traktowały to jako pretekst do ingerencji w wewnętrzną politykę Turcji. W tym okresie położenie chrześcijan, a zwłaszcza zamieszkujących obszary peryferyjne Ormian, uległo pogorszeniu.

Również wojny rosyjsko-perskie siały wielkie spustoszenie na terytorium Azerbejdżanu Północnego, w tym i na terenie Karabachu. Szacuje się, że w wyniku działań militarnych populacja chanatu spadła do 30-40\% stanu przedwojennego ${ }^{5}$. We wrześniu 1905 r., po porażce w wojnie z Japonią, uwage caratu pochłonęły strajki i chłopskie powstania. Rewolucja rozpoczęła się 22 stycznia w Petersburgu od wydarzeń tzw. krwawej niedzieli. Następnie przerodziła się w ogólnokrajowy zryw skierowany przeciw terrorowi stosowanemu przez władze wobec obywateli. Rozruchy ogarnęły także Zakaukazie, przyjmując często formę lokalnych walk ormiańsko-azerbejdżańskich. Głównym ośrodkiem zamieszek było Baku. Starcia objęły także miasta i okolice: Szuszy, Nachiczewanu, Erywania, Tbilisi, Kazachu i Zangezuru. Zniszczeniu uległo 128 ormiańskich i 158 muzułmańskich wiosek a łączna liczba ofiar wahała się od 3000 do 10 000. Kolejna fala przemocy od stycznia do sierpnia 1906 r. miała miejsce w Szuszy, a następnie w Karabachu, Nachiczewaniu i Erywaniu?

Wzajemne pogromy powtarzały się co kilka lat ${ }^{8}$ Największą sitę przybrały w 1918 r., kiedy ormiańskie bojówki dasznackie wspierane przez bolszewików dokonały w Baku w dniach od 31 marca do 2 kwietnia tzw. rzezi ludności muzułmańskiej. Wydarzenia okre-

\section{- • • •}

3 W 1978 r. w Mardakercie odsłonięto pomnik dla uczczenia 150-lecia kolonizacji ormiańskiej w tej części Azerbejdżanu. Interesującym jest, że Ormianie w latach 90., już po zbrojnym zajęciu Karabachu zdemontowali z pomnika pierwotny napis i przekształcili go w pomnik upamiętniający Ormian karabachskich.

4 T. Świętochowski, Azerbejdżan i Rosja. Kolonializm, islam i narodowość w podzielonym kraju, Warszawa 1998, s. 21-24.

5 В. Baranowski, K. Baranowski, Historia Azerbejdżanu, Wroctaw 1987, s. 132; Х. Д. Халилов, Из истории Kaрабаха [w:] История Азербайджана..., оp. cit., s. 39-41. Kolejny spis ludności w Karabachu przeprowadzono pod koniec XIX w.; wykazał on, że z 54841 rodzin tu żyjących, 29350 było narodowości azerbejdżańskiej, a 18616 ormiańskiej, pozostałe zaś zaliczono do tzw. innych narodowości.

6 О. Качазнуни, Дашнакцутюн больще нечего делать!, Баку 1990, s. 78-89; T. Świętochowski, Azerbejdżan i Rosja..., op. cit., s. 54.

7 C. van der Leeuw, Storm Over the Caucasus, in the Wake of Independence, Richmond 1999, s. 69-71.

8 Кавказский календарь 1917 г., s. 190-197. W 1917 r. z 574194 osób zamieszkujących terytorium Karabachu, 317861 deklarowało narodowość azerbejdżańską, a 243627 ormiańską, pozostali byli przedstawicielam innych nacji. 
ślane przez historiografię azerbejdżańską mianem Dni Marcowych pociągnęły za sobą około 3000 ofiar, z czego dużą liczbę stanowili emigranci z Persji. W ciągu dziesięcioleci wypadki te opisywane były jako wojna domowa, sprowokowana przez dasznaków i azerbejdżańskich musawatystów, która doprowadziła do zwycięstwa bolszewików i powstania komuny bakijskiej ${ }^{9}$. Zakończenie I wojny światowej przyniosło państwom zakaukaskim krótki okres niepodległości. Dnia 22 kwietnia 1918 r. Sejm Zakaukaski ogłosit niepodległość Zakaukaskiej Federacyjnej Republiki Demokratycznej. W jej skład weszły 3 terytoria: Azerbejdżan, Armenia i Gruzja. Jednak Federacja targana politycznymi sporami od początku skazana była na niepowodzenie. Działacze partyjni stawiali interesy narodowe ponad ogólnozakaukaskie. Antagonizmy były zbyt duże, aby można było utrzymać taką formę wspólnoty. Gruzini i Ormianie nastawieni byli antyturecko, ale dzielił ich spór dotyczący przebiegu wspólnej granicy, natomiast Azerbejdżanie liczyli na pomoc Turcji w osiągnięciu autonomii. Sprzeczności te doprowadziły do secesji i 26 maja Rada Narodowa proklamowała niepodległość Gruzji, co de facto oznaczało likwidację republiki10.

Po konfliktach z lat 1905-1907 i 1918-1920 Karabach stał się częścią mitu narodowego Armenii. Ustanowienie władzy radzieckiej w listopadzie 1920 r. spowodowało, że Karabach uznany został za część składową republiki. Jednak w lipcu 1921 r. kaukascy przedstawiciele Rosyjskiej Komunistycznej Partii bolszewików (RKPb), wbrew woli ludności ormiańskiej zamieszkującej sporne terytorium, anulowali poprzednią decyzję i przekazali Górski Karabach Azerbejdżanowi pod warunkiem, że Baku przyzna mu szeroką autonomię. Obwód oficjalnie utworzono 7 lipca 1923 r. ${ }^{11}$

Lata władzy radzieckiej paradoksalnie doprowadziły do wzmocnienia azerbejdżańskiej tożsamości narodowej kosztem wspólnoty muzułmańskiej, identyfikacji językowej kosztem jedności islamskiej. Bolszewicy obawiali się bowiem bardziej panislamizmu niż azerbejdżańskiego nacjonalizmu. Takie posunięcia, jak wprowadzenie alfabetu łacińskiego, czy polityka korienizacji z lat 20. ułatwiały tworzenie poczucia narodowego. Wraz z umocnieniem władzy Stalina zintensyfikowano działania na rzecz laicyzacji Azerbejdżanu. Wiosną 1927 r. ogłoszono akcję hudżum na rzecz emancypacji kobiet, które zachęcano do zrzucenia zasłon noszonych na twarzy - czarczafów. Władze przystąpiły do zamykania meczetów, dyskredytowania duchownych m.in. pod zarzutem szpiegostwa. Polityka stalinowska polegała na popieraniu azerbejdżańskiego partykularyzmu przy równoczesnej rusyfikacji. Przykładem powodzenia tej taktyki stało się Baku, najbardziej aktywne miasto w latach konfliktu karabachskiego i rządów nacjonalistycznego Ludowego Frontu Azerbejdżanu (LFA), które jest niemal zupełnie laickie, a jego mieszkańcy rosyjskojęzyczni, w przeciwieństwie choćby do Tbilisi, gdzie język rosyjski na ulicy należy do rzadkości ${ }^{12}$.

Twierdzenie, że w czasach Związku Radzieckiego konflikt karabachski nie istniał, można odnosić jedynie do militarnego stadium. W tym okresie ormiańskie władze wysunęły 16 propozycji przemianowania Górnokarabachskiego Obwodu Autonomicznego (GKOA) Azerbejdżańskiej SRR w GKOA Armeńskiej SRR oraz 45 propozycji dotyczących usankcjonowanego prawnie przejścia GKOA w skład Republiki Armenii ${ }^{13}$. Ormianie przeważali

-・・・

9 Рабочее движение в Азербайджане в годы Документы и материалы, Баку 1967, Т. 1, S. 35-38.

10 Н. Насибзаде, Внешняя политика Азербайджана (1918-1920), Баку 1996, s. 13-22; J. Kawtaradze, Gruzja w zarysie historycznym, Warszawa 1929, s. 141-143. Dnia 28 maja 1918 Armenia i Azerbejdżan powołały oddzielne rządy i ogłosiły, odpowiednio, powstanie Demokratycznej Republiki Azerbejdżanu i Demokratycznej Republiki Armenii.

11 T. Świętochowski, Ropa a stabilność polityczna w basenie Morza Kaspijskiego, „Eurazja” nr 1/1996, s. 29-31.

12 R. W. Strayer, Why Did the Soviet Union Collapse?: Understanding Historical Change, New York-London 1998, s. 71-74.

13 C. Mutafian, Karabagh in the Twentieth Century, [w:] The Caucasian Knot, The History and Geo-Politics of Nagorno-Karabakh, pod red. L. Chorbajian, P. Donabediasn, C. Mutafian, London 1994, s. $127-155$. 
w populacji Karabachu, przez nich obsadzone były stanowiska w nomenklaturze i milicji. W języku ormiańskim prowadzono administrację publiczną, nadawały lokalna telewizja i radio, ukazywały się gazety i książki. Odróżniało to karabachską autonomię od pozostałych tego typu jednostek w Związku Radzieckim, w których wytyczną było używanie języka państwowego republiki związkowej. Dążenia do oderwania GKOA od Azerbejdżanu skupiały Ormian wokół haseł narodowościowych, których historyczną kanwą była walka z odwiecznym wrogiem Turkami-muzułmanami. Ogłoszenie przez Gorbaczowa nowego kursu w polityce, pierestrojki, spowodowało, że Ormianie uwierzyli w możliwość realizacji planów dotyczących Górskiego Karabachu. Jednak w procesie przekształceń systemu komunistycznego władze nie wypracowały spójnej polityki narodowościowej.

\section{ESKALACJA KONFLIKTU W LATACH 1988-1994}

Rozpoczęcie najnowszej fazy sporu przypadło na 1987 r. ${ }^{14} \mathrm{~W}$ większości kołchozów, przedsiębiorstw i instytucji Górskiego Karabachu odbywały się zebrania pracownicze, na których domagano się zjednoczenia GKOA z Armenią. W październiku doszło do pierwszych starć na tle etnicznym w rejonie Kafanu. W wyniku rozruchów kilkuset Azerbejdżan zmuszonych zostało do opuszczenia domów ${ }^{15}$. Do 25 stycznia 1988 r. ich liczba osiągnęła 4000. W okresie od października 1987 do grudnia 1988 r., z powodów narodowościowych i religijnych, Armenię opuściło łącznie około 180000 Azerbejdżan i Kurdów wyznających islam ${ }^{16}$.

Na terytorium Górskiego Karabachu od 12 lutego 1988 r. trwały demonstracje, które z czasem, tak jak w Askeranie, przerodzity się w antyazerbejdżańskie wystąpienia. Protestujący domagali się przyłączenia Karabachu do Armeńskiej SRR. Jednak za oficjalny po-

\section{$\cdots \cdots$}

14 р. Мустафаев, Преступления армянских бандитских и террористических формирований против человечества (XIX-XXI вв.), Баку 2002, s. 105-115; Ф. Ахундов, Кто виноват в карабахском тупике?, „Россия в глобальной политике", Т. 6, nr 1/2008, s. 192-202; Террористические акты, совершенные в пассажирских и грузовых поездах, http://www.mns.gov.az/terroractspart2_ru.html, dostęp z dnia 8.08.2010; Международный терроризм и этнополитические конфликты, http://www.bakililar.az/kolonka/terror.html, dostęp z dnia 11.08.2010. Do ataków terrorystycznych dochodziło już na początku lat 80. Jednak pierwszym, poważniejszym było wysadzenie w 1984 r. autobusu pasażerskiego w Baku. Zginęła wówczas jedna kobieta, a 9 osób zostało rannych. Akcja przeprowadzona została w odwecie za masakry Ormian w Anatolii Wschodniej w 1915 r. Sprawcy najprawdopodobniej nie działali w zorganizowanej grupie, gdyż te powstały pod koniec lat 80. Wtedy na terytorium Armenii zaczęli pojawiać się działacze fundacji ormiańskich i diaspory z Francji, Grecji, Iranu, Libanu, Rosji i Stanów Zjednoczonych. Najbardziej znaną ormiańską organizacją terrorystyczną działającą m.in. w Górskim Karabachu była ASALA (Tajna Ormiańska Armia dla Wyzwolenia Armenii), która zyskała rozgłos zamachami na dyplomatów tureckich na całym świecie. Przeprowadzała także zamachy na cywilne cele, aby zmusić rząd turecki do uznania pogromów Ormian z 1915 r. za ludobójstwo. W sprawie karabachskiej ASALA ściśle współpracowała z utworzoną w 1988 r. w Moskwie, organizacją „Ormiańska Jedność". Najkrwawsze akcje terrorystyczne przeprowadzone przez Ormian w Azerbejdżanie miały miejsce w latach 1989-1990. Były to m.in. ataki bombowe na autobusy pasażerskie na trasie Baku-Tbilisi oraz Agdam -Tbilisi. Ormianie w walce o Karabach nie ograniczali się tylko do terytorium Azerbejdżanu. Dnia 8 kwietnia 1991 r. w Rostowie nad Donem doszło do zabójstwa zastępcy dowódcy wojsk Ministerstwa Spraw Wewnętrznych ZSRR na Zakaukaziu i Północnym Kaukazie, pułkownika Władimira Blachotina. W latach 19911994 Ormianie dokonali poza tym zamachów bombowych na 6 pociągów międzynarodowych łączących Baku z rosyjskimi miastami. Największy rozgłos zyskały jednak ataki przeprowadzone na bakińskie metro w 1994 r. Według azerbejdżańskich służb bezpieczeństwa stała za nimi lezgińska organizacja "Sadwal", która ściśle współpracowała z ormiańskimi służbami specjalnymi. W okresie od 1986 do 1994 r. w Azerbejdżanie przeprowadzono ponad 100 aktów terrorystycznych, a około 20 udało się zapobiec. Nie licząc zamachów na wojskowych oraz urzędników państwowych w Górskim Karabachu, ataki terrorystyczne przeprowadzono na 6 autobusów, 14 cywilnych helikopterów, prom i 2 ataki na metro bakińskie. Zginęło w nich łącznie około 200 osób, a ponad 1800 zostało rannych. Ginęli nie tylko Azerbejdżanie, ale także Lezgini, Ormianie, Rosjanie, Tatarzy i Żydzi.

15 T. de Waal, Black Garden: Armenia and Azerbaijan through Peace and War, New York 2003, s. 202-209; Beyond the Soviet Union: The Fragmentation of Power, red. M. Beloff, Farnham 1997, s. 44-47.

16 А. Юнусов, Погромы в Азербайджане в 1988-1990 годах, „Экспресс-Хроника”, nr 9/1991, 26 lutego 1991. 
czątek współczesnego konfliktu przyjmuje się datę 20 lutego 1988 r., kiedy na sesji Rady Obwodowej GKOA postanowiono zwrócić się do rad najwyższych: ZSRR, Azerbejdżańskiej SRR i Armeńskiej SRR o wykluczenie Górskiego Karabachu z Azerbejdżanu i przyłączenie go do Armenii. Podejmując tę uchwałę, Rada GKOA dała wyraz nastrojom, jakie panowały wówczas wśród Ormian zamieszkujących Karabach ${ }^{17}$. Swoje poparcie dla tej decyzji wyrażali także mieszkańcy Armenii, uczestnicząc w licznych wiecach będących wyrazem solidarności z rodakami znajdującymi się pod azerbejdżańskim zwierzchnictwem.

Największa manifestacja odbyła się 23 lutego 1988 r. w Erywaniu. Uczestniczyło w niej około miliona osób. Kiedy Moskwa kategorycznie odrzuciła petycję władz karabachskich, w Armenii rozpoczęły się masowe protesty. W ich konsekwencji ogłoszono ogólnonarodowy strajk, który doprowadził tylko do eskalacji napięć. Dnia 22 lutego zginęło 2 Azerbejdżan, a 19 osób zostało rannych. Po kilku dniach informacje o krwawych incydentach w Askeranie dotarły do miejscowości Sumgait. Walki trwały od 27 lutego, kiedy kilkudziesięcioosobowe grupy, składające się także uchodźców z Armenii zaczęły napadać na Ormian, do 1 marca $^{18}$. W wyniku starć śmierć poniosło 26 Ormian oraz 6 Azerbejdżan, około 130 osób zostało rannych. Aresztowano 97 osób, w tym 93 Azerbejdżan, 2 Rosjan, Ormianina i Lezgina. Według oficjalnych danych zginęły wówczas 32 osoby. Szacuje się jednak, że ofiar mogło być znacznie więcej, nawet 400. Rozruchy odbywały się przy całkowitej bierności wojska i milicji19. Na skutek zajść do Armenii przybyło ponad 3000 uchodźców z Sumgaitu. Ich relacje przypominały doniesienia opisujące rzezie Ormian dokonywane przez Turków w 1915 r. Wydarzenia te okazały się przełomowymi, gdyż ostatecznie zamykały możliwość jakiegokolwiek dialogu między zantagonizowanymi stronami. W obawie przed dalszymi pogromami rozpoczęły się masowe migracje ${ }^{20}$.

Dochodzenia w sprawie wypadków z Askeranu, Sumgaitu i Baku nigdy nie zostały zakończone, pozostawiając wiele kontrowersji. Najważniejsze z nich dotyczyły tego, kto odpowiada za zarzewie konfliktu. Do dziś niewyjaśniona pozostaje rola, jaką odegrał Ormianin Eduar Grigorian, uznany za jednego z aktywniejszych uczestników pogromów. Grigoriana skazano co prawda na 12 lat więzienia za zabicie 5 rodaków²1, jednak już po kilku latach zwolniono go na mocy amnestii. Kolejną problematyczną kwestią była indolencja sił porządkowych, które w początkowej fazie nie podjęły żadnych prób rozdzielenia walczących stron, mimo iż wojsko zostało uprzedzone o demonstracjach i przebywało na terytorium Sumgaitu22. Wypadki w Sumgaicie doprowadziły do zmian we władzach obydwu republik. Decyzją M. Gorbaczowa, Karen Demirczian i Kamran Bagirow zostali w maju odwołani. Na stanowiskach: I sekretarza Armeńskiej Partii Komunistycznej oraz Azerbejdżańskiej Partii Komunistycznej zastąpili ich tzw. „ludzie Gorbaczowa” - Suren Arturian i Abdulrahman (Abdurahman) Wezirow ${ }^{23}$. Plenum Górsko-Karabachskiego Komitetu Obwodowego KPZR dnia 17 marca 1988 r. poparło postulaty Rady Obwodowej GKOA o przyłączenie do Armeńskiej SRR. Na dążenia karabachskich Ormian przychylnie

\section{......}

17 S. Goldenberg, Pride of Small Nations: The Caucasus and Post-Soviet Disorder, London 1994, s. 161-163.

18 В. Богданович, Конфликты и войны после распада СССР, Киев 2008, s. 365-368.

19 А. Юнусов, Погромы в Азербайджане в 1988-1990 годах, „Экспресс-Хроника", nr 21/1991, 21 таја 1991.

20 А. Юнусов, Армяно-Азербайджанский конфликт: Демографические и миграционные аспекты, „Центральная Азия и Кавказ", nr 16/1998, http://www.ca-c.org/journal/16-1998/st_10_junusov.shtml, dostęp z dnia 08.09.2010.

21 Ostateczna liczba osób zabitych przez E. Grioriana zmienia się zależnie od wykorzystanych źródet, jest to 5 bądź 6 osób. Por. T. de Waal, Black Garden..., op. cit., s. 42-43; Данные приведены в отчетном докладе Секретариата Центрального Комитета от 11 июня 1988 г. РАП, фонд 89, рол. 1003, 89/33/11; Р. Kwiatkiewicz, Azerbejdżan: uksztaltowanie niepodległego państwa, Toruń 2009, s. 77.

22 J. Modrzejewska-Leśniewska, Konflikt armeńsko-azerbejdżański 1990-1993, [w:] Zarys dziejów Afryki i Azji 1896-1996. Historia konfliktów, pod red. A. Bartnickiego, Warszawa 1998, s. 400-402.

23 A. Yunusov, Karabakh: past and present, Baku 2005, s. 38-39. 
zareagowała także Rada Najwyższa Armenii, która 15 czerwca oficjalnie wyraziła zgodę na wejście GKOA w skład terytorium republiki24. Reakcja azerbejdżańskich władz była natychmiastowa. W dniach 13 i 17 czerwca 1988 r. Rada Najwyższa republiki przyjęła uchwały potwierdzające, iż transfer GKOA w skład Armeńskiej SRR na podstawie art. 78 konstytucji ZSRR oraz art. 70 konstytucji Azerbejdżańskiej SRR nie jest możliwy. Decyzje podjęte przez Ormian spotkały się również z negatywnym odzewem najwyższych władz w Moskwie ${ }^{25}$.

W dniu 7 grudnia 1988 r. wstrząsnęło Armenią, w okolicach Leninakanu i Spitaku, potężne trzęsienie ziemi. Co najmniej 25000 osób zginęło, a 500000 straciło dach nad głową, 10000 dzieci zostało sierotami. Wydarzenia te pogłębiły napięcia polityczne. Wśród ofiar było wielu uchodźców z Azerbejdżanu, którzy zostali przesiedleni do północnej Armenii, w pobliże epicentrum trzęsienia ziemi. W ciągu następnych 18 miesięcy około 300000 Azerbejdżan zostało wysiedlonych z terytorium Armenii26.

W styczniu 1989 r. Prezydium Rady Najwyższej ZSRR wprowadziło szczególną formę rządu w Górskim Karabachu. Zgodnie z przyjętym przez Radę Najwyższą ZSRR dekretem utworzono Komitet Zarządzania Specjalnego GKOA pod przewodnictwem Arkadija Wolskiego. Nie doprowadziło to jednak do spodziewanego złagodzenia napięć. Azerbejdżanie uważali, iż w czasie zarządzania obwodem przez moskiewską centralę w praktyce wyłączono go spod jakiejkolwiek władzy kierownictwa Azerbejdżańskiej SRR co w konsekwencji doprowadziło do nasilenia ormianizacji na spornym terytorium ${ }^{27}$.

Likwidacji uległy punkty agencji informacyjnych, m.in. Azerinform. Zwalniano azerbejdżańskich urzędników, nawet jeżeli ich stanowiska pochodziły z wyboru. Pozamykano azerbejdżańskie szkoły, a w Stepanakercie zamknięto azerbejdżański wydział Instytutu Pedagogicznego. Symboliczne znaczenie miało usunięcie w GKOA flag i emblematów Azerbejdżańskiej SRR. Z państwowych pieczątek wymazano nazwe "Górsko-Karabachski Obwód Autonomiczny Azerbejdżańskiej SRR"28. Na odbywającym się 16 sierpnia 1989 r. zjeździe „pełnomocnych przedstawicieli ludności” Górsko-Karabachskiego Obwodu Autonomicznego jednomyślnie ogłoszono odmowę uznania statusu Górskiego Karabachu jako jednostki znajdującej się w składzie Azerbejdżańskiej SRR i powołano Krajową Radę GKOA ${ }^{29}$. Tym samym w Górskim Karabachu powstała dwuwładza: Komitet pod przewodnictwem A. Wolskiego, któremu pośrednio podlegało wojsko i Rada Ludowa oraz 78-osobowa Krajowa Rada GKOA ${ }^{30}$. Reakcja władz azerbejdżańskich była natych-

…...

24 А. Манасян, Карабахский конфликт. Ключевые понятия и хроника, Ереван 2005, s. 118-120.

25 Постановление Президиума Верховного Совета Азербайджанской ССР „О ходатайстве депутатов Совета народных депутатов Нагорно-Карабахской автономной области о передаче области из Азербайджанской ССР в состав Армянской ССР”, 13 июня 1988 г., „Бакинский рабочий”, 14 czerwca 1988 г. Постановление Верховного Совета Азербайджанской ССР „О ходатайстве депутатов Совета народных депутатов Нагорно-Карабахской автономной области о передаче НКАО из состава Азербайджанской ССР в Армянскую ССР”, 17 июня 1988 г., „Ведомости Верховного Совета Азербайджанской ССР”, nr 11-12/1988, s. 72; Т. Мусаев, Правовые рамки урегулирования вопросов территории и грании на примере территориальных притязаний Армении к Азербайджану, „Центральная Азия и Кавказ”, nr 2/2003, s. 44-47; И. Маммадов, Т. Мусаев, Армяноазербайджанский конфликт: история, право, посредничество, Баку 2008, s. 57-58.

26 C. Cox, J. Eibner, Ethnic Cleansing in Progress: War in Nagorno Karabakh, London 1993, http://sumgait.info/ caroline-cox/ethnic-cleansing-in-progress/karabakh-question-revived.htm, dostęp z dnia 12.09.2010.

27 T. de Waal, Black Garden..., op. cit., s. 67-72; S.E. Cornell, The Nagorno-Karabakh Conflict, Department of East European Studies, Report no. 46, Uppsala 1999, s. 21-23.

28 о положении в Нагорно-Карабахской Автономной Области Азербайджанской ССР и мерах преодоления кризиса в межнациональных отношениях, [w:] История Азербайджана по документам и публикациям, Баку 1990, s. 337-341. Świadectwa dojrzałości w 1989 r. w Karabachu zostały wydane w imieniu Ministerstwa Edukacji Narodowej Armeńskiej SRR.

29 М. Саркисян, Нагорный Карабах: война и политика (1990-93 г2.), Ереван 2010, s. 21-22.

30 T. de Waal, Black Garden..., op. cit., s. 85-86. W styczniu 1990 r. na czele Komitetu stanął Wiktor Polianiczenko. 
miastowa. Dnia 26 sierpnia Prezydium Rady Najwyższej Azerbejdżańskiej SRR przyjęło uchwałe „O niekonstytucyjnych działaniach w Górsko-Karabachskim Obwodzie Autonomicznym", uznając decyzje podjęte na zjeździe pełnomocnych przedstawicieli ludności GKOA za bezprawne ${ }^{31}$

Kuratela Moskwy zakończyła się niepowodzeniem. Ormianie otwarcie dążyli do połączenia GKOA z Armeńską SRR, na co kategorycznie nie wyrażały zgody władze azerbejdżańskie i żadne pośrednie rozwiązania nie były rozpatrywane. Dnia 28 listopada 1989 r. Komitet przekształcono w organ wojskowy, tzw. Komitet Organizacyjny, który podporządkowany został azerbejdżańskiemu rządowi, Centralnemu Komitetowi Komunistycznej Partii Azerbejdżanu i Radzie Najwyższej Azerbejdżańskiej SRR. Strona ormiańska działania władz radzieckich uznała za zdradę. Dnia 1 grudnia 1989 r. w Erywaniu podczas wspólnych obrad Rady Najwyższej Armeńskiej SRR i Rady Ludowej Górskiego Karabachu przyjęto postanowienie o zjednoczeniu się GKOA z Armeńską SRR. Decyzja ta spowodowała zaostrzenie sytuacji i wzrost wzajemnych animozji32.

Międzynarodowa opinia publiczna zajęła proormiańskie stanowisko. Przyczyniła się do tego w znacznej mierze ormiańska diaspora, organizująca w wielu miastach, m.in. w Bejrucie, Bostonie, Los Angeles i Moskwie, manifestacje mające na celu ukazanie światu niedoli rodaków. Natomiast azerbejdżańskie demonstracje były znacznie gorzej przygotowane, często przeradzały się w antyormiańskie zamieszki, które przyczyniały się do śmierci niewinnych osób, pokojowo koegzystujących z muzułmanami33. Takie zachowania tylko potęgowały negatywny wizerunek Azerbejdżan na świecie. Radzieckie środki masowego przekazu nie reagowały na wypędzenie prawie 200000 Azerbejdżan z terytorium Armenii. Analogiczne sytuacje dotyczące Ormian były natychmiast piętnowane. Deputowani do Rady Najwyższej ZSRR, przedstawiciele ministerstwa komunikacji i dziennikarze jawnie wyrażali oburzenie z powodu przerwania dostaw dla Armenii linią kolejową prowadzącą przez Azerbejdżan. Nikt nie uwzględniał faktycznego stanu rzeczy, iż działania te stanowiły reperkusje wprowadzenia blokady wobec nachiczewańskiej enklawy ${ }^{34}$.

Decyzja Rady Najwyższej Armenii z dnia 10 stycznia 1990 r. o objęciu Górskiego Karabachu republikańskim budżetem oraz przyznaniu jego mieszkańcom prawa głosu w wyborach do organów partyjnych i państwowych w Armenii była kolejnym krokiem prowadzącym do eskalacji konfliktu ${ }^{35}$. Media w Azerbejdżanie rozpowszechniały nie zawsze potwierdzone informacje o napadach, dokonanych przez ormiańskie bandy, na wsie w okolicach Szaumianu i Chanlaru. Wiadomości te wywoływały działania odwetowe, zwłaszcza przeciwko Ormianom mieszkającym w Baku. Jeszcze na początku 1990 r. żyło ich tam około 30 000-40 000. W mieście przebywała także bardzo duża grupa rozgoryczonych uchodźców z Armenii, którzy swą frustrację zaczęli wyładowywać na miejscowej ludności ormiańskiej. W społeczeństwie coraz większą popularność zdobywał utworzony w lipcu 1989 r. Ludowy Front Azerbejdżanu (LFA). Jego członkowie rekrutowali się przede wszystkim ze środowisk studenckich. Działacze LFA powołali Radę Obrony Narodowej, której głównym zadaniem miała być ochrona nacjonalistycznych interesów, granic,

\section{$\cdots \cdots$}

31 C. Mutafian, Karabakh in the Twentieth Century..., op. cit., s. 112-113; Постановление Президиума Верховного Совета Азербайджанской ССР „О неконституционной акции в НКАО”, 26 августа 1989 г., „Ведомости Верховного Совета Азербайджанской ССР", nr 15-16/1989, s. 21-22.

32 И. Маммадов, Т. Мусаев, Армяно-азербайджанский конфликт..., op. cit., s. 59

33 D.E. Miller, L.T. Miller, Armenia: Portraits of Survival and Hope, California 2003, s. 37-41.

34 T. Świętochowski, Azerbejdżan i Rosja..., op. cit., s. 229-230.

35 D.M. Kiedrowski, Wydarzenia w Karabachu Górskim, [w:] Kaukaz w dobie globalizacji, pod red. A. Furiera, Poznań 2005, s. 106; C. Mouradian, The Mountainous Karabakh Question: Inter-Ethnic Conflict or Decolonization Crisis, "Armenian Review”, t. 43, nr 2-3, 1990, s. 27-28. 
przywrócenie azerbejdżańskiej symboliki, historycznych nazw geograficznych i eliminacja zrusyfikowanych nazwisk ${ }^{36}$.

Dnia 12 stycznia 1990 r. przedstawiciele radykalnego skrzydła LFA, którzy weszli w skład Rady Obrony Narodowej - Nemat Panahow i Rahim Gazijew wystąpili w lokalnej telewizji z komunikatem, iż do Baku trafiła duża liczba bezdomnych uchodźców, gdy tymczasem kilka tysięcy Ormian w dalszym ciągu żyło w komfortowych warunkach. Następnego dnia odbyła się duża antyormiańska manifestacja. Wieczorem niektórzy z rozchodzących się demonstrantów zaczęli napadać na mieszkania zajmowane przez Ormian³7. Napastnicy posługiwali się wykazem zamożniejszych osób narodowości ormiańskiej. W zamieszkach trwających 2 dni bezpośrednio śmierć poniosło 46 Ormian, Azerbejdżanin i Rosjanin, 20 kolejnych osób zmarło w szpitalach z powodu odniesionych ran, 6 osób zmarło bez udziału osób trzecich, w tym z powodu zawału serca bądź samobójstwa. W milicyjnych kartotekach odnotowano w tych dniach także 5 gwałtów, 2044 napady na mieszkania i 191 rozbojów ${ }^{38}$

Wystąpienia antyormiańskie przybrały radykalną formę. Jednak milicja i wojsko nie wkroczyły, mimo iż w Baku stacjonowało wówczas 12000 żołnierzy ministerstwa spraw wewnętrznych ${ }^{39}$. Dnia 15 stycznia Prezydium Rady Najwyższej ZSRR przyjęło dekret o wprowadzeniu stanu wyjątkowego w GKOA oraz wzdłuż zachodniej i południowej strefy pogranicza z ZSRR ${ }^{40}$. Dostęp do enklawy był utrudniony. Oddziały Armii Czerwonej oraz azerbejdżańskiej milicji zablokowały trasy dojazdowe. Jedynym otwartym szlakiem do Górskiego Karabachu pozostała droga lotnicza z Erywania do Stepanakertu. Była ona dostępna tylko dla posiadaczy radzieckich paszportów z dowodem zameldowania w Górskim Karabachu lub dysponujących pozwoleniem sztabu generalnego ${ }^{41}$.

LFA był bardzo bliski przejęcia władzy w republice. Sondaże przewidywały jego zwycięstwo w wyborach zaplanowanych na marzec 1990 r. Wprowadzenie stanu wyjątkowego przez centrum związkowe zablokowało możliwość takiego rozwoju wypadków i pozwoliło utrzymać się przy władzy partii komunistycznej w Azerbejdżanie ${ }^{42}$. Militarna interwencja nastąpiła dopiero po kilku dniach od rozpoczęcia zamieszek. Doszło do niej dopiero wtedy, gdy Baku opuścili ostatecznie wszyscy Ormianie i część ludności rosyjskiej, a sytuacja się ustabilizowała. W okolicach Baku skoncentrowano ponad 55000 żołnierzy. Członkowie LFA, przygotowując się na interwencję wojsk radzieckich, budowali w mieście barykady. Dnia 19 stycznia komandosi si specjalnych z grupy szturmowej „Alfa” oraz jednostki wojsk lądowych, morskich i spadochronowych pod ogólnym dowództwem generała Aleksandra Lebiedzia, natarły z 3 stron na miasto. Akcja ta odbywała się pod hasłami stłumienia muzułmańskiego fundamentalizmu, przywrócenia porządku w republice i ochrony Rosjan, "brutalnie mordowanych przez miejscowych ekstremistów"43.

Nastąpiły starcia uliczne. Wojsko, często bez powodu, otwierało ogień do zgromadzonej ludności. Zgodnie z oficjalnymi danymi tylko w Baku zginęły 132 osoby (w pozostałych

36 T. Świętochowski, Azerbaijan: a borderland at the crossroads of history, [w:] The Legacy of History in Russia and the New States of Eurasia, red. S.F. Starra, New York 1994, s. 287-292; M. Saroyan, The "Karabakh Syndrome" and Azerbaijani Politics, "Problems of Communism", nr 39/1990, s. 14-19.

37 T. de Waal, Black Garden..., op. cit., s. 90. Poza Nematem Panahowem i Rahimem Gazijewem członkam Rady byli Etibar Mamiedow i Abulfaz Elczibej.

38 R. Kushen, Conflict in the Soviet Union: Black January in Azerbaidzhan, Human Rights Watch, New York 1991, s. 7

39 F. Tsertisivadze, The forgotten genocide, New York 2005, s. 80-81.

40 Продолжение геноцида армян?, Ереван 2006, s. 7-8.

41 The Nagorno-Karabakh Conflict. A Legal Analysis, red. H. Krüger, Berlin-Heidelberg 2009, s. 99-101.

42 N. Cafersoy, Azerbaijan Foreign Policy in Elchibey Era, Diplomatic Story of an Independence Struggle, Ankara 2001, s. 22-23.

43 Ч.А. Султанов, Намествие..., Второе издание, дополненное, Т. 1, Баку 2004, s. 419-425. 
rejonach republiki 26 Azerbejdżan), a 744 zostały ranne, pojawiły się również dane mówiące o śmierci ponad 170 cywili. Śmierć poniosło także 29 radzieckich żołnierzy ${ }^{44}$. W przeważającej części od ognia własnych oddziałów, co było wynikiem braku skoordynowanego dowodzenia. Po wkroczeniu wojsk radzieckich, 20 stycznia także na Baku rozciągnięto dekret o stanie wyjątkowym.

Radziecka interwencja z założenia miała na celu udowodnienie, że Moskwa nadal posiada władzę w Azerbejdżanie. Przyczyniła się jednak do jej upadku, doprowadzając do antyradzieckich wystąpień. W pogrzebach "styczniowych ofiar" uczestniczyło około 2000000 osób. Ludzie wykrzykiwali hasła: "Gorbaczow jest zabójcą”, „Komunistyczna Partia ZSRR - idźcie do domu", "Okupanci do domu". Niszczono wszystko, co miało jakikolwiek związek z partią, m.in. uszkodzono pomnik Lenina, pozrywano tablice z nazwami ulic, które miały cokolwiek wspólnego ZSRR, a 10000 działaczy KPA demonstracyjnie spaliło legitymacje członkowskie. Ogłoszono żałobę narodową, a następnie 40-dniowy strajk ${ }^{45}$. Ze stanowiska I sekretarza KPA ustąpił A. Wezirow, a na jego miejsce powołano Ajaza Mutalibowa. Bardzo ostro na działania Moskwy zareagowała także Rada Najwyższa Azerbejdżańskiej SRR, która przyjęła uchwałę domagającą się wycofania wojsk radzieckich i zniesienia wprowadzonego przez władze związkowe stanu wyjątkowego ${ }^{46}$.

Styczniowe wydarzenia doprowadziły do fali gwałtownych antyazerbejdżańskich wystąpień w Armenii, a karabachscy Ormianie zaczęli tworzyć paramilitarne oddziały, wzorowane na dasznackich. Napadały one na miejscowych Azerbejdżan, ale zdarzało się, że ostrzeliwały i przeprowadzały ataki na wsie znajdujące się po drugiej stronie granicy. W celu ich demilitaryzacji, jesienią 1990 r. do GKOA wprowadzono azerbejdżańskie Oddziały Milicji Specjalnego Przeznaczenia (OMON). Jednakże z powodu niedofinansowania i korupcji oddziały te w krótkim czasie zaczęły działać jak grupy przestępcze.

Ludność Górskiego Karabachu żyła w poczuciu ciągłego zagrożenia. Z tego powodu okazywała wsparcie nielegalnym formacjom wojskowym, często traktując je jako gwaranta swego bezpieczeństwa. Wsie i miejscowości znajdujące się w strefie walk zamieniły się w lokalne twierdze, w których organizowano siły samoobrony. Grupy takie tworzyły się po obu stronach konfliktu. Do starć między nimi dochodziło aż do maja $1991 \mathrm{r}$. W ciągu pierwszych 4 miesięcy 1991 r. miało miejsce kilkadziesiąt napadów na ormiańskie i azerbejdżańskie wsie. Zginęło w nich około 30 cywili, a wiele osób zostało rannych. Branie zakładników, kradzieże i uprowadzenia bydła stało się codziennością. Zwiększyła się również liczba napadów na wojskowe i milicyjne posterunki ${ }^{47}$.

Ostatnią próbą rozwiązania konfliktu, jaką podjęły władze radzieckie, była operacja pod kryptonimem „Pierścień”. W 4 przygranicznych regionach: ararackim, goriskim, idżewańskim i nejembriańskim toczyły się walki z użyciem artylerii i czołgów. Azerbejdżański OMON i wojska radzieckie MSW zablokowały ormiańskie wsie Martunaszen i Getaszen. Działaniami militarnymi objęto także tereny Armenii. Przykładem był los przygranicznej wsi Woskepar, którą 7 maja doszczętnie zniszczono, używając broni ciężkiej i lotnictwa. Zginęło wówczas kilkadziesiąt osób. Akcje, które w założeniu miały polegać na kontroli dowodów osobistych i rozbrajaniu Ormian i Azerbejdżan, przerodziły się w pogromy i deportacje $^{48}$.

44 R. Kushen, Conflict in the Soviet Union..., op. cit., s. 30.

45 M. Saroyan, The Karabakh Syndrome..., op. cit., s. 29.

46 Ю.А. Помпеев, Кровавый омут Карабаха, Баку 1992, s. 56-59.

47 T. de Waal, Black Garden..., op. cit., s. 114-115. W 1990 r. zanotowano 117 bandyckich napadów, a w ciągu pierwszych czterech miesięcy 1991 r. już 128.

48 M.P. Croissant, The Armenia-Azerbaijan Conflict: Causes and Implications, London 1998, s. 40-43. 
Pod koniec listopada 1991 r. armia radziecka przestała „separować” strony konfliktu, co przyczyniło się do walk na szeroką skalę. Prowadzenie regularnych działań zbrojnych możliwe było także dzięki polityce władz ZSRR oraz postępowaniu niektórych dowódców garnizonów radzieckich (po rozpadzie ZSRR w grudniu 1991 r. rosyjskich) stacjonujących na Zakaukaziu49. W lutym 1992 r. Ormianie rozpoczęli niezwykle ważną pod względem strategicznym operację militarną. Jej celem było zajęcie korytarza laczyńskiego łączącego terytorium Górskiego Karabachu z Republiką Armenii. Wcześniej z Erywania do Stepanakertu można było dostać się jedynie samolotem, przechodząc przez szczegółową kontrolę radzieckich wojsk i azerbejdżańskiej milicji, lub - jak to robili ormiańscy fedaini - przedzierając się przez góry.

Ogromny wstrząs społeczny w Azerbejdżanie wywołały wydarzenia w miejscowości Chodżały ${ }^{50}$, zamieszkanej głównie przez Azerbejdżan, także tych przesiedlonych z Armenii i Stepanakertu oraz kilkadziesiąt rodzin Turków meschetyńskich przybyłych z Uzbekistanu po wydarzeniach w Kotlinie Fergańskiej ${ }^{51}$. Miasto zostało zablokowane przez siły ormiańskie, odcięto dostawy prądu, a jedynym środkiem łączącym Chodżały ze światem były śmigłowce. Jednak kiedy nad Szuszą Ormianie strącili samolot z 40 osobami na pokładzie, zawieszono i ten środek komunikacji. Zbrojne siły w mieście składały się głównie z nielicznych oddziałów samoobrony wspieranych przez milicję i azerbejdżańską armię narodową ${ }^{52}$. Wieczorem 26 lutego wspomagający oddziały ormiańskie 366. putk piechoty zmechanizowanej armii rosyjskiej zajął pozycje bojowe i rozpoczął kilkugodzinny ostrzał artyleryjski. Następnie na Chodżały z trzech stron natarły oddziały ormiańskie oraz rosyjskie. Miejscowa ludność zmuszona została do ucieczki jedyną dostępną drogą wiodącą do Askeranu. Jednakże wzdłuż trasy rozlokowano stanowiska karabinów maszynowych. Żołnierze otworzyli zaporowy ogień do uciekających. Wówczas zginęło najwięcej ofiar ${ }^{53}$.

$W$ protokołach sporządzonych natychmiast po masakrze podawano, że zginęło ponad 1000 cywili. Z czasem azerbejdżańskie władze obniżyły tę liczbę do 700 osób. Ostateczne dochodzenie ustaliło, że w wyniku ormiańsko-rosyjskiego ataku zginęło 613 osób, 1275 wzięto do niewoli, 150 zaginęło, 487 zostało rannych lub trwale okaleczonych. Wśród zabitych było 63 dzieci, 106 kobiet i 70 starców, 8 rodzin całkowicie unicestwiono. Kilkadziesiąt ofiar, według źródeł azerbejdżańskich, zabito ze szczególnym okrucieństwem, panowała opinia, że Ormianie mścili się za pogromy w Sumgaicie i Baku5. Parlamentarzyści powołali specjalny zespół, który miał doprowadzić do uznania przez międzynarodowe sądy mordów w Chodżałach za zbrodnie ludobójstwa.

Wydarzenia w Chodżałach oraz ofensywa ormiańska na Szuszę i Laczyn spowodowały poważny kryzys polityczny. Azerbejdżanie byli poruszeni informacjami napływającymi z frontu. FLA organizowało masowe protesty, oskarżając prezydenta Mutalibowa o indo-

\section{-....}

49 Na mocy Układu o bezpieczeństwie zbiorowym WNP z 15 maja 1992 r., tzw. taszkienckiego, Rosja przekazała określone ilości uzbrojenia Armenii i Azerbejdżanowi, realizując podział majątku armii radzieckiej. Regularnie dozbrajała także Ormian szczególnie, kiedy poprzez ofensywę ormiańską chciała wywrzeć presję na azerbejdżańskie władze. Do zwiększenia ilości broni w rękach obu stron przyczynity się także kradzieże z magazynów i napady na rosyjskie transporty wojskowe, które często miały zatuszować rzeczywiste transakcje pomiędzy rosyjskimi dowódcami i stronami konfliktu.

50 Miasto znajduje się na drodze łączącej Agdam z Szuszą oraz Askeran i Stepanakert. W jego pobliżu usytuowane było jedyne lotnisko w Górskim Karabachu.

51 Kotlina Fergańska podzielona jest między Kirgistan, Tadżykistan i Uzbekistan. Stanowi jeden z najgęściej zaludnionych obszarów Azji Środkowej. Szerzej: S. Zapaśnik, "Walczący Islam” w Azji Centralnej. Problem spotecznej genezy zjawiska, Wrocław 2006, s. 68-97.

52 F. Tsertisivadze, The forgotten..., op. cit., s. 110-115.

53 T. Goltz, Azerbaijan Diary: A Rogue Reporter's Adventures in an Oil-rich, War-torn Post-Soviet Republic, New York 1998, s. 117-130.

54 Х. Мамедова, Ходжалы: шехиды и шахиды, Баку 2004, s. 20-21. 
lencję oraz zaniechania w tworzeniu armii narodowej, która skutecznie przeciwstawiłaby się ormiańskiej ofensywie. Na początku marca odbyła się specjalna sesja parlamentu poświęcona wydarzeniom z linii walk. Po 2 dniach debat i ostrej krytyce skierowanej przeciwko reżimowi prezydenta, Mutalibow 5 marca ustąpił ze stanowiska, a jego petnomocnictwa przejął przewodniczący parlamentu Jakub Mamedow ${ }^{55}$. Kraj pogrążał się w chaosie. W ramach akcji odwetowej azerbejdżańscy żołnierze 10 kwietnia 1992 r. przeprowadzili zmasowany atak na miejscowość Maraga. Według różnych szacunków zamordowano od 80 do 100 osób, w tym 30 kobiet, około 40 mieszkańców Maragi zostało rannych, a 63 zostały uprowadzone w tym 9 dzieci56.

Dnia 16 czerwca 1992 r. prezydentem mianowany został nacjonalista Abulfaz Elczibej ${ }^{57}$. Jednak mimo zapewnień, że krwawo rozprawi się z "separatystami z Karabachu” nie udało mu się rozwiązać konfliktu z Armenią. W okresie jego prezydentury wojsko odniosto co prawda największe sukcesy na froncie, jednak z czasem w armii ujawnity się te same negatywne czynniki, które trawiły ją w okresie rządów Mutalibowa. Szerzyła się korupcja, a przez defraudację środków finansowych żołnierze cierpieli na braki w ekwipunku oraz zaopatrzeniu. Upowszechniła się dezercja. Słabością azerbejdżańskich sił zbrojnych było także to, iż składały się one głównie z tzw. prywatnych i partyjnych oddziałów. Powszechne było werbowanie zagranicznych najemników. Po stronie azerbejdżańskiej walczyli Rosjanie, obywatele Afganistanu i Turcji. Ormianie również zaciągali do wojska Rosjan, Irańczyków, Libańczyków i Syryjczyków. Było to dla nich o tyle łatwe, że w krajach tych znajdowały się liczne ormiańskie diaspory ${ }^{58}$.

KONKLUZJE

Podczas prezydentury Elczibeja uwidoczniły się problemy typowe dla republik poradzieckich. Brakowało doświadczonych urzędników, którzy nie byliby związani z dotychczasowym aparatem partyjnym. Przedstawiciele komunistycznych elit powrócili na wcześniej zajmowane stanowiska. Panował nepotyzm, a wszelkie przejawy demokratyzacji były skutecznie tłamszone. Problem stanowiła także rosyjska ludność cywilna, która nie identyfikowała się z nowym państwem, oraz stacjonująca w Azerbejdżanie 47-tysięczna Czwarta Armia. Władze borykały się również z brakiem gospodarczej samowystarczalności. Polityczny kryzys związany z usunięciem Elczibeja z urzędu prezydenta wykorzystały ormiańskie oddziały, które przeszły na całej linii frontu do natarcia. Armia azerbejdżańska przestała istnieć i nie pomogło jej zrekrutowanie 2500 bojowników z Afganistanu ${ }^{59}$. W państwie

55 М. Волхонский, В. Муханов, Россия на Кавказе: пять веков истории научно-публицистические очерки, Москва 2009, s. 328-330.

56 R. Denber, R.K. Goldman, Bloodshed in the Caucasus: escalation of the armed conflict in Nagorno Karabakh, Human Rights Watch, New York, 1992, s. 29.

57 T. Świętochowski, Azerbejdżan i Rosja..., op. cit., s. 258-259. Abulfaz Elczibej wyprowadzit Azerbejdżan z WNP, nie zgodził się także na dalsze stacjonowanie wojsk rosyjskich w kraju, dążył do zawarcia ścisłego sojuszu z Turcją w ramach ideologii panturkijskiej i rozpoczął przygotowania do podpisania kontraktów naftowych z zachodnimi koncernami naftowymi.

58 T. de Waal, Black Garden..., op. cit., s. 235-237.

59 G.E. Curtis, Armenia, Azerbaijan and Georgia: country studies, Washington 1995, s. 142-144. Według danych MFW i rządu Azerbejdżanu, wydatki obronne stanowiły poważne obciążenie dla państwa. W 1992 r. wynosity 125000000 dolarów, co stanowiło 10,5\% całego budżetu. Konflikt o Karabach przyczynił się również do zwiększenia do 4000000000 rubli, nakładów na bezpieczeństwo wewnętrzne. W 1994 r. wydatki wojskowe sięgnęły 132000000 dolarów, choć według nieoficjalnych szacunków były znacznie wyższe. 
zapanował chaos, którego konsekwencją było nie tylko utracenie do końca 1993 r. Górskiego Karabachu, ale także 7 innych rejonów ${ }^{60}$.

W wyniku zaostrzenia walk, w lutym 1994 r. odbyły się w Rydze bilateralne rozmowy mające na celu powstrzymanie eskalacji przemocy. Były one prowadzone na poziomie partii niepodległościowych. Jednakże delegaci LFA oraz Ormiańskiego Ruchu Narodowego (ANM) nie osiągnęli konsensu, wobec czego dalsze rokowania przerwano. Władzę w Azerbejdżanie przejął Hejdara Alijewa, któremu nie udało się doprowadzić do zakończenia konfliktu drogą militarną, jednak podpisał zawieszenie broni z Ormianami. Szczególną rolę W uregulowaniu konfliktu karabachskiego przyjęło KBWE (OBWE) ${ }^{61}$. Mediacji podjęła się również strona rosyjska. Wspólne działania przyczyniły się do podpisania $w$ dniach 9-12 maja 1994 r. w Biszkeku protokołu o zaprzestaniu walk. Dokument parafowali ministrowie obrony Armenii, Azerbejdżanu oraz nieuznawanego rządu Republiki Górskiego Karabachu. Na jego mocy Azerbejdżan utracił 14\% terytorium państwa. Prezydent Alijew wykorzystał tę sytuacje do wprowadzania autorytaryzmu i cenzury, uzasadniając to antagonizmami z Armenią. Za jego rządów nastąpił także znaczny wzrost powiązań klanowych w życiu politycznym i gospodarczym, co łączyło się z rozwojem korupcji w kraju.

Natomiast Lewon Ter-Petrosjan, prezydent Armenii w latach 1991-1998, stał na stanowisku, iż podpisze każde rozwiązanie, które wcześniej zostałoby zaakceptowane przez przywódców Ormian karabachskich. Był on zwolennikiem niepodległości Karabachu. Uważał jednak, że wojska ormiańskie powinny oswobodzić okupowane azerbejdżańskie tereny wokół Karabachu. Liczył, że Turcja i Azerbejdżan zniosą wówczas transportową i ekonomiczną blokadę Armenii. Ujawnienie tych poglądów w jednym z wywiadów wywołało burze w kraju, doprowadzając do dymisji Ter-Petrosjana i rozpisania w marcu 1998 r. przedterminowych wyborów, które wygrał Robert Koczarian. Dnia 27 października 1999 r. miało miejsce wydarzenie, które znacznie wzmocniło pozycję karabachskiego klanu na scenie politycznej. Do gmachu parlamentu wtargnęła uzbrojona grupa pod dowództwem Nairi Unaniana i otworzyła ogień do deputowanych ${ }^{62}$. Zginęło 8 osób: premier Wazgen Sarkisjan, przewodniczący parlamentu Karen Demirczian, minister ds. nadzwyczajnych Leonard Pietrosian, wicespikerzy Rubien Mirojan i Jurij Bachszian oraz posłowie Armienak Armienakian, Henrik Abramian i Mikajeł Kotanian. Do dziś nie wiadomo, kto stał za zamachem, faktem jest jednak, iż jego skutki wzmocniły pozycję prezydenta63. Konflikt ciągle oddziaływał więc na wewnętrzną sytuację w Azerbejdżanie i Armenii, angażując dodatkowo takie kraje jak Rosja, Iran i Turcja. Z Górskiego Karabachu wywodzili się kolejni prezydenci Armenii Robert Koczarian i Serż Sarkisjan. Przyczyniło się to do tzw. karabachizacji kraju, gdyż najważniejsze stanowiska w państwie zajmowali politycy wywodzący się ze spornego terytorium. Porozumienie z Biszkeku nie jest restrykcyjnie respektowane, na

$\cdots \cdot \cdot$

60 А. Абасов, А. Хачатрян, Варианты решения карабахского конфликта: идеи и реальность, Баку 2002, s. 29-30. W wyniku przeprowadzonych ormiańskich operacji wojskowych zajętych zostało 7 regionów Azerbejdżanu (5 całkowicie i 2 częściowo) niewchodzących w skład byłego GKOA.

61 Dnia 24 marca 1992 r. na szczycie KBWE w Helsinkach powołało tzw. Grupę Mińską - wyspecjalizowany zespół negocjatorów z 11 państw, których głównym zadaniem było rozwiązanie sporu. Jej celem było doprowadzenie do przerwania walk ormiańsko-azerbejdżańskich, a następnie do konferencji pokojowej.

62 F. Tsertisivadze, The forgotten..., op. cit., s. 7-9; Ch. Hille, State Building and Conflict Resolution in the Caucasus, Leiden 2010, s. 251-253. Oskarżonym Nairi Unanianowi, jego bratu Karienowi oraz Eduardowi Grigorianowi, Derenikowi Biedżanianowi, Wramowi Gałstianowi i Aszotowi Kniazianowi postawiono 7 zarzutów. Najważniejszymi z nich były: zdrada stanu, terroryzm, zorganizowana działalność przeciw państwu. Skazano ich na dożywocie, natomiast Hamlet Stiepanian otrzymał kare 14 lat pozbawienia wolności.

63 С.М. Искандеров, Внутриполитические аспекты нагорно-карабахского конфликта, [W:] Om Майендорфа до Астаны: принципиальные аспекты армяно-азербайджанского нагорно-карабахского конфликта, pоd red. Г.М. Алексеева, Москва 2010, s. 321-322. 
linii rozejmowej zdarzały się wymiany ognia ${ }^{64}$. Po obu stronach żołnierze ginęli w wyniku wybuchów min lub od kul snajperów. W trakcie konfliktu śmierć poniosło około 25000 osób, a 50000 zostało rannych. Działaniom zbrojnym towarzyszyły także wielkie ruchy migracyjne. Według danych z czerwca 1994 r. zjawisko to w samym Azerbejdżanie objęło ponad 1100000 osób. W latach 1989-1994 z Armenii wyjechało 800000 osób. W szczytowym momencie przebywało na jej terytorium około 600000 uchodźców z terytoriów objętych działaniami zbrojnymi. Pomimo napływu uciekinierów z Azerbejdżanu liczba ludności Armenii od 1991 r. zmniejszyła się z 3600000 do $3200000^{65}$.

Władze w Baku utrzymują, iż podstawowym warunkiem, na jakim może zostać zbudowany i przestrzegany pokój, jest zasada integralności terytorialnej. Wynika z niej, że możliwe jest tylko takie rozwiązanie, które zakładałoby przynależność Górskiego Karabachu do Azerbejdżanu. Z kolei Ormianie opierają się na prawie narodów do samostanowienia, które według nich uprawomocniło ogłoszenie niepodległości przez Republikę Górskiego Karabachu. Spór pozostaje jednym z kluczowych problemów destabilizujących Zakaukazie. Stanowi także przeszkodę dla zagranicznych inwestycji w Armenii. Mimo mediacji podejmowanych przez międzynarodowe organizacje i bilateralnej, często markowanej, dyplomacji nie udało się osiągnąć kompromisu. Konflikt w ostatnich latach zaostrzył się. Szczyt OBWE w Astanie 1-2 grudnia 2010 r. doprowadził wręcz do impasu w rozmowach pokojowych. Dnia 22 października azerbejdżański parlament zatwierdził projekt budżetu na 2011 r., w którym przewidziano niemal dwukrotny wzrost wydatków na obronność (3 100000000 dol.), co stanowi 1/5 całego budżetu państwa. Decyzja o zwiększeniu budżetu wojskowego w okresie natężonego napięcia miała przede wszystkim wydźwięk propagandowy, świadczy jednak również o tym, że władze azerbejdżańskie, z prezydentem Ilhamem Alijewem na czele, nie wykluczają siłowego rozwiązania66. Dnia 25 lutego 2010 r. minister obrony Azerbejdżanu Safar Abijew po raz kolejny zagroził, iż jeżeli Armenia nie wycofa wojsk z okupowanych terytoriów wokół Górskiego Karabachu, Baku może rozpocząć działania zbrojne ${ }^{67}$. Ostrzeżenia przed eskalacją konfliktu znalazły się również w raporcie pozarządowej organizacji International Crisis Group (ICG). Wyścig zbrojeń, eskalacja walk na froncie, wojenna retoryka i podział w rozmowach pokojowych zwiększają tylko szansę Armenii i Azerbejdżanu na powrót do stanu wojny ${ }^{68}$.

\section{$\cdots \cdots$}

64 Karabach: siłowa "dyplomacja”, "Tydzień na Wschodzie”, nr 29 (147)/2010, s. 9. W dniach 31 sierpnia i 4 września 2010 strona azerbejdżańska ostrzeliwała i prowadziła działania dywersyjne wymierzone w siły samozwańczej Republiki Górskiego Karabachu. Ograniczony charakter starć i straty w ludziach, które ponieśli głównie Azerbejdżanie, wydają się być wpisane w polityczną ofensywę Baku zmierzającą do nagłośnienia konfliktu karabaskiego i pokazania determinacji w zabiegach o przywrócenie kontroli nad separatystyczną republiką. W ostrzale i nieudanych akcjach dywersyjnych inicjowanych - najprawdopodobniej - przez stronę azerbejdżańską zginąć miało 2-7 żołnierzy azerbejdżańskich i 1-2 ormiańskich. Choć do wymiany ognia w rejonie konfliktu dochodzi regularnie, obecne starcia były najpoważniejsze w ostatnich miesiącach. Łącznie w 2010 r. w wyniku incydentów zbrojnych na linii frontu zginęło co najmniej 30 osób.

65 Crossroads and Conflict: Security and Foreign Policy in the Caucasus and Central Asia, red. Gary K. Bertsch, London 2000, s. 169-171.

66 Военный эксперт об оборонном бюджете, дедовщине в армии Армении и вероятности возобновления войны в Карабахе, Day.Az, http://news.day.az/politics/234904.html, dostęp z dnia 06.08.2010; Кавказ-News, http://www.kavkaz-news.info/portal/cnid_118525/alias_Caucasus-Info/lang_en/tabid_2434/default.aspx, dostęp 06.08.2010

67 К. Али, Приближается угроза новой войны на Кавказе - Сафар Абиев, „Новости-Азербайджан”, 25 lutego 2010, http://www.novosti.az/security/20100225/43298548.html, dostęp 9.08.2010; I. Snip, Azerbaijan warns Armenia of a "great war", "Evolutsia.Net. Musings on Georgian politics, the Caucasus, and all things Khachapuri", 2 marca 2010, http://www.evolutsia.net/azerbaijan-warns-armenia-of-a-great-war/, dostęp 9.08.2010.

68 Armenia and Azerbaijan: Preventing War, International Crisis Group, http://www.crisisgroup.org/en/regions/ europe/caucasus/B60-armenia-and-azerbaijan-preventing-war.aspx, dostęp 15.03.2011. Siły zbrojne Azerbejdżanu szacowane są na blisko 95000 żołnierzy, natomiast łącznie Armenii i Karabachu na 70000. 


\section{FACES OF THE ARMENIA-AZERBAIJAN CONFLICT IN NAGORNO-KARABAKH}

\section{Summary}

The territory of Nagorno-Karabakh had become the matter of Armenian-Azerbaijani disputes long before the establishment of the Soviet power in the Caucasus. The colonization of Armenian citizens at the Muslim territories had been rising after every conflict which the Russian Empire was involved in. Especially after the Crimean War and Russian War which took place between 1876-1878. After the conflicts which took place between 1905-1907 and 1918-1920 Karabakh became a part of Armenian national myth. The establishment of the Soviet power in November 1920 resulted in recognition of Karabakh as a part of one Republic. The fact that during the times of the Soviet Union the conflict didn't exist can be only related to the military state. The begining of the current phase took place in 1987 the Armeni Supreme Council's decision from 10 $10^{\text {th }}$ January 1990 about covering the NagornoKarabakh in the budget and granting the citizens the right to vote in general elections was another step leading to escalation of the conflict. The authorities in Baku maintain that the essential condition is the principal of territorial integrity. It says that the resolution which would assume the integration of Azerbaijan and Nagorno-Karabakh to be the only one and proper. On the other hand the Armenians relate to the law of nations, and aspire to self-determination. According to them the declaration of independence became effective. The dispute is still one of the key problems destabilizing the situation in the furthest part of the Caucasus.

Keywords: Nagorno-Karabakh, Armenia, Azerbaijan, the Caucasus, conflict 